\title{
OS PRESSUPOSTOS DO DEVIDO PROCESSO PENAL NO ESTADO DEMOCRÁTICO DE DIREITO
}

\section{THE ASSUMPTIONS OF THE DUE CRIMINAL PROCESS IN THE DEMOCRATIC STATE OF LAW}

\author{
Daniel Prates Sternick* \\ Michel Wencland Reiss ${ }^{* *}$
}

\begin{abstract}
RESUMO
O presente trabalho busca proporcionar uma revisão crítica acerca da origem de algumas bases conceituais e interpretativas que norteiam a atividade processual penal no intuito de oferecer um substrato epistemológico que seja capaz, ainda que minimamente, de fugir da grande inflação que vem sofrendo o direito processual penal como um todo. Para tanto, primeiramente, analisa-se o processo enquanto instrumento de tutela, haja vista que toda e qualquer finalidade meramente satisfativa, isto é, de efetivação da norma incriminadora, devem ser interpretadas secundariamente à proteção da dignidade da pessoa humana, sob pena de subversão da própria essência do processo penal. Depois, a fim de introduzir uma visão alternativa sobre seu objeto que perpasse, em todas as óticas, pela primazia dos direitos fundamentais, expõe-se uma recusa ao conceito de pretensão punitiva por trazer consigo um notório resquício autoritário e inquisitorial. Portanto, o que se pretende é a fixação de premissas necessárias para a consecução de um devido processo penal condizente com as exigências de um Estado Democrático de Direito.
\end{abstract}

Palavras-chave: Direito processual penal. Sistema garantista. Jurisdicionariedade. Direitos fundamentais. Estado Democrático de Direito.

\begin{abstract}
This work seeks to provide a critical review about the origin of some conceptual and interpretative bases that guide criminal procedural activity in order to offer an epistemological substrate that is able, even if minimally, to escape the great inflation that has been suffering the criminal procedural law as a whole. To this end, we first analyze the process as an instrument of protection, considering that any and all merely satisfactory purposes, i.e., to enforce the incriminating norm, should be interpreted secondarily to the protection of human dignity, under penalty of subverting the very essence of criminal procedure. Then, to introduce an alternative view on its object that passes, in all perspectives, by the primacy of the fundamental rights, it is exposed a refusal to the concept of punitive claim for bringing with it a notorious authoritarian and inquisitorial remnant. Therefore, the intention is to set the necessary premises for the achievement of a due criminal process in accordance with the requirements of a Democratic State of Law.
\end{abstract}

Keywords: Criminal procedure law. Guarantee system. Jurisdictionality. Fundamental rights. Democratic State of Law.

Artigo submetido em: 15 de maio de 2021 e aprovado em 19 de julho de 2021.

* Discente na Faculdade Mineira de Direito da Pontifícia Universidade Católica de Minas Gerais - PUC Minas. Email: d.sternick@hotmail.com

*** Mestre em Ciências Penais pela UFMG. Doutor em Direito pela PUC-Rio. E-mail: michelwreiss@gmail.com. 


\section{INTRODUÇÃO}

As bases conceituais e interpretativas trabalhadas no âmbito do direito processual penal há muito vem sendo analisadas sob óticas questionáveis que, em linhas gerais, costumam adequar-se aos fenômenos do processo civil e advir de uma teoria geral do processo. Isso, ainda que de forma involuntária, acaba por estimular uma utilização desmesurada e desproporcional do processo penal, configurando uma verdadeira disfunção, posto que desvirtua todos os seus fundamentos. O presente artigo, tendo isso em vista, possui o intuito de proporcionar uma leitura mais adequada aos princípios constitucionais do processo penal contemporâneo, abordando o fundamento de sua existência e o objeto por ele tratado.

Em primeiro lugar, não se pretende recusar o chamado modelo constitucional de processo, sendo inegável a existência de regras gerais atinentes ao processo judicial constitucional, na esteira do que sustenta o professor Ronaldo Brêtas quando reconhece a garantia do devido processo legal como viga-mestra do processo constitucional (DIAS, 2015, p. 118-166). Assim, por óbvio que o direito processual - como um todo - deve estar em conformidade com os regramentos constitucionais, todavia isso não altera o fato de ser no processo penal que a dignidade da pessoa humana, princípio reitor da Constituição da República, é colocada em xeque. Dignidade esta que é compreendida como um meta-princípio, visto que

irradia valores e vetores de interpretação para todos os demais direitos fundamentais, exigindo que a figura humana receba sempre um tratamento moral condizente e igualitário, sempre tratando cada pessoa como fim em si mesma, nunca como meio (coisa) para satisfação de outros interesses ou de interesses de terceiros. (FERNANDES, 2015, p. 358).

Apenas para melhor compreensão, destaque-se que Gonçalves Fernandes ainda argumenta pela necessidade de se conceber verdadeiros parâmetros de aferição da dignidade da pessoa humana, recusando, assim, atribuir a esse princípio uma imprecisão e amplitude tão extensa que o permitisse ser encaixado em toda e qualquer situação (FERNANDES, 2015, p. 360-361). Sendo assim, o autor sustenta quatro parâmetros, sendo eles: (i) não instrumentalizaçãoo, ou seja, a impossibilidade de se valer do ser humano para satisfação de determinada finalidade, haja vista ser ele um fim em si mesmo; (ii) autonomia existencial, traduzida na possibilidade de coexistência entre diferentes projetos de vida, no pluralismo; (iii) mínimo existencial ou a presença de condições materiais básicas para todos indistintamente; (iv) direito ao reconhecimento, pois em determinados casos não basta a redistribuição de bens materiais ante a invisibilidade social que rodeia determinadas parcelas desfavorecidas da população.

Em suma, não é suficiente garantir formalmente uma igualdade no processo sem levar em conta as assimetrias sociais e históricas presentes nos contextos. Sem esse tipo de problematização, a densificação normativa continuará insensível perante determinados grupos vulneráveis. Por isso, não basta defender uma igualdade material a fim de inserir minorias sociais no seio de uma sociedade que não as aceita, não as reconhece e não as respeita.

Feitos tais esclarecimentos, entende-se que o princípio da dignidade da pessoa humana encontra no processo penal um verdadeiro campo minado não somente em virtude da limitação de diversos direitos fundamentais, mas, especialmente, por conta da privação de liberdade que eventualmente será imposta ao término do processo ou até mesmo durante seu curso, de forma cautelar. Isso porque o sistema carcerário brasileiro constitui um notório descalabro, sendo de amplo conhecimento alheio a situação caótica e desumana em que se encontram os presos no país. Não à toa, afirmou o professor Heleno Fragoso que "a prisão necessariamente avilta, deforma a personalidade e corrompe o condenado.” (FRAGOSO, 2004, p. 5) 
Nessa linha também entendeu o Supremo Tribunal Federal (STF), quando, no bojo da Arguição de Descumprimento de Preceito Fundamental (ADPF) no 347 , reconheceu o estado de coisas inconstitucional que assola o sistema prisional no Brasil. Na oportunidade, o relator, Min. Marco Aurélio, proferiu a seguinte assertiva:

\begin{abstract}
[...] no sistema prisional brasileiro, ocorre violação generalizada de direitos fundamentais dos presos no tocante à dignidade, higidez física e integridade psíquica. A superlotação carcerária e a precariedade das instalações das delegacias e presídios, mais do que inobservância, pelo Estado, da ordem jurídica correspondente, configuram tratamento degradante, ultrajante e indigno a pessoas que se encontram sob custódia. As penas privativas de liberdade aplicadas em nossos presídios convertem-se em penas cruéis e desumanas. Os presos tornam-se "lixo digno do pior tratamento possível", sendo-lhes negado todo e qualquer direito à existência minimamente segura e salubre. (BRASIL, 2015).
\end{abstract}

A partir das supracitadas palavras de um ministro da mais alta Corte do país, torna-se forçoso concluir que, na prática, não existe dignidade humana para presos no Brasil. É por isso que Lopes Jr., analisando o paradoxo do tempo no Direito e na sociedade, assevera que a pena privativa de liberdade "gera grave defasagem enquanto tempo de involução." (LOPES JR., 2018, p. 50).

Para além disso, há mais problemas. Afinal, ainda que o indivíduo submetido ao processo penal seja absolvido ou, se condenado, não sofra privação de liberdade propriamente dita, certo é que já será punido pelo simples fato de figurar como acusado em um processo criminal. Nesse mesmo sentido lecionou Luigi Ferrajoli quando disse que a inflação do processo penal - ou seu uso desmesurado - faria com que ele acabasse se tornando "uma sanção talvez mais odiosa que a própria pena tradicional" (FERRAJOLI, 2002, p. 587). O autor italiano vai adiante ao afirmar que essa disfunção nos permitiria concluir pela existência de penas processuais, tratando-as como uma verdadeira patologia judicial

[...] que assinala a possibilidade de fazer uso do processo como escopo de punição antecipada, ou de intimidação policialesca, ou de estigmatização social, ou de persecuções políticas, ou por todos estes motivos conjuntamente. Em todos os casos, além de cada intenção persecutória em relação ao suspeito, é indubitável que a sanção mais temida na maior parte dos processos penais não é a pena - quase sempre leve ou não aplicada - , mas a difamação pública do imputado, que tem não só a sua honra irreparavelmente ofendida mas, também, as condições e perspectivas de vida e de trabalho; e se hoje pode-se falar de um valor simbólico e exemplar do direito penal, ele deve ser associado não tanto à pena mas, verdadeiramente, ao processo e mais exatamente à acusação e à amplificação operada sem possibilidade de defesa pela imprensa e pela televisão (FERRAJOLI, 2002, p. 587).

Denota-se, portanto, que o processo penal possui o potencial condão de prejudicar e marcar um cidadão ainda quando improcedente a acusação. ${ }^{1}$ Plausível ressaltar que essa punição antecipada pode se dar mediante imposição de medidas cautelares patrimoniais, haja vista que privar o indivíduo de seu patrimônio pode gerar graves consequências até mesmo para a subsistência de seus familiares. Essa situação ainda é agravada pela dilação indevida do processo porquanto "o caráter punitivo está calcado no tempo de submissão ao constrangimento estatal, e não apenas na questão espacial de estar intramuros." (LOPES JR, 2019, p. 78). E digase: será duplamente agravada quando explorada, em termos espetaculares e tendenciosos, por parte de uma mídia descompromissada com os imperativos de proteção da dignidade humana.

\footnotetext{
1 Assim também entende Lopes Jr.: “[...] o processo se transforma em pena prévia à sentença, através da estigmatização, da angústia prolongada, da restrição de bens e, em muitos casos, através de verdadeiras penas privativas de liberdade aplicadas antecipadamente (prisões cautelares).” (LOPES JR., 2019, p. 79-80).
} 
Cabe apontar, porém, que a Constituição Federal consagrou, em abstrato, a maioria senão todas - das garantias que serão abordadas a seguir como inerentes ao fundamento do processo penal. Entretanto, o cerne da questão se dá no momento de consagrá-las em concreto, tendo em vista o abismo existente entre as previsões do ordenamento jurídico brasileiro e a práxis cotidiana, ou, melhor dizendo, "o imenso hiato entre o mundo normativo concebido em 1988 e a realidade das práticas sociais e culturais vivenciadas pelo povo e também pelas instituições e agentes públicos" (CRUZ, 2019, p. 41).

Fato é que nosso sistema penal, embora formalmente garantista, tem se mostrado efetivamente autoritário, cuja prática cada vez mais se dissocia das promessas democráticas positivadas na Constituição. Nessa toada, faz-se essencial rever alguns aspectos relevantes para a consecução do processo penal como instrumento de proteção ao indivíduo, a fim de caracterizá-lo como verdadeiramente democrático, de modo que a "atividade repressora do Estado jamais se afaste das conquistas civilizatórias” (CRUZ, 2019, p. 53).

\section{A CONSTITUIÇÃO COMO FUNDAMENTO DO PROCESSO PENAL DEMOCRÁTICO}

Almejando uma melhor contextualização do processo penal democrático sobre o qual se baseia o presente artigo, buscar-se-á uma exposição de seus elementos fundantes dando ênfase a algumas singularidades. Nessa senda, o primeiro passo a ser dado passa inexoravelmente por uma compreensão sobre o que caracteriza esse referido processo penal, ou, de outra forma, o porquê de sua existência.

É deveras disseminada uma interpretação do processo como sendo um mecanismo de efetivação do direito material aplicável ao caso eventualmente colocado sob tutela jurisdicional, constituindo, portanto, um verdadeiro instrumento com a finalidade de trazer aplicação concreta a um direito abstratamente previsto numa norma material. Seguindo essa linha, Fredie Didier Jr. sustenta que:

\footnotetext{
O processo deve ser compreendido, estudado e estruturado tendo em vista a situação jurídica material para a qual serve de instrumento de tutela. A essa abordagem metodológica do processo pode-se dar o nome de instrumentalismo, cuja principal virtude é estabelecer a ponte entre o direito processual e o direito material. (DIDIER JR., 2019, p. 79-80).
}

Mesmo sem ter a pretensão de invalidar ou recusar essa concepção no presente artigo, abordar-se-á o caráter instrumental do processo partindo de algumas premissas relativamente distintas daquelas comumente utilizadas no âmbito da teoria geral ou, mais notadamente, do processo civil. Isso porque, ainda que se admita no processo penal a finalidade de satisfazer uma pretensão posta sob o crivo do Poder Judiciário, há de se convir que ele assume feições mais marcantes ${ }^{2}$ e, por assim dizer, de observância imediata.

Dessa forma, a noção de instrumentalidade do processo penal será analisada primeiramente sob o prisma do princípio da submissão à jurisdição, ou estrita jurisdicionariedade, cunhado em 1989 pelo jurista italiano Luigi Ferrajoli na célebre obra "Diritto e ragione: teoria del garantismo penale"3, para que, depois, seja possível um afunilamento acerca do que alguns autores conceituam como princípio da necessidade.

\footnotetext{
${ }^{2} \mathrm{Cf}$. abordagem feita acerca da dignidade da pessoa humana e demais direitos fundamentais.

3 Traduzida para o espanhol com o título "Derecho y razón: teoría del garantismo penal”. Posteriormente, em 2002, foi publicada no Brasil como "Direito e razão: teoria do garantismo penal".
} 


\subsection{Princípio da submissão à jurisdição: breve leitura de Luigi Ferrajoli}

Inicialmente, cumpre mencionar que Ferrajoli, ao formular a teoria do garantismo penal, propõe um sistema de garantias escorado em dez axiomas fundamentais ${ }^{4}$ que visam, ao mesmo tempo, limitar e legitimar a intervenção penal do Estado. Limitar, pois a intervenção penal está estritamente vinculada à observância dos axiomas, e legitimar, pois, se devidamente respeitados, estaria, em tese, autorizada - mas não necessariamente em caráter obrigatório - a tutela penal. Não necessariamente em caráter obrigatório porque o modelo penal garantista

[...] não é em absoluto incompatível com a presença de momentos valorativos, quando estes, em vez de se dirigirem a punir o réu para além dos delitos cometidos, servem para excluir sua responsabilidade ou para atenuar as penas segundo as específicas e particulares circunstâncias nas quais os fatos comprovados se tenham verificado (FERRAJOLI, 2002, p. 34).

Em outros termos, seria dizer que a observância do sistema de garantias "não se trata de uma condição suficiente, na presença da qual esteja permitido ou obrigatório punir, mas sim de uma condição necessária, na ausência da qual não está permitido ou está proibido punir." (FERRAJOLI, 2002, p. 74). Morais da Rosa vai nesse mesmo sentido ao aduzir que os axiomas representam condições

prescritivas de regras processuais ideais ao modelo garantista sem que o seu preenchimento in totum obrigue uma sanção; mas o contrário, pois somente com o preenchimento (de to)das implicações deônticas do modelo é que o sistema está autorizado a emitir um juízo condenatório. (ROSA, 2005, p. 131).

Dentre os dez princípios axiológicos estabelecidos pelo mestre italiano, os seis primeiros correspondem às ditas garantias penais, enquanto os quatro últimos dizem respeito às garantias processuais, sem olvidar, ainda, dos diversos teoremas logicamente derivados de possíveis silogismos entre os axiomas (FERRAJOLI, 2002, p. 75). O presente artigo, ainda que perpasse de forma pontual pelas garantias penais, centrar-se-á no exame das garantias relativas ao processo.

O princípio da jurisdicionariedade, ou submissão à jurisdição, é refletido pelo axioma nulla culpa sine iudicio (A7), e constitui, segundo o próprio autor, a principal garantia processual, uma vez que a partir dela tem-se o pressuposto para todas as demais (FERRAJOLI, 2002, p. 432). Ferrajoli trata a jurisdicionariedade a partir de uma dupla dimensão - em sentido lato e em sentido estrito - visto que traduzem premissas distintas:

Em sentido lato, pode ser expressa pela tese T72 "nulla poena, nullum crimen, nulla
lex poenalis, nulla necessitas, nulla iniuria, nulla actio, nulla culpa sine iudicio"-, em
sentido estrito, pela tese T63 "nullum iudicium sine accusatione, sine probatione et
sine defensione". Com base no primeiro princípio o juízo é simplesmente uma
exigência do conjunto das garantias penais ou substanciais; com base no segundo, por
sua vez, é requerido o conjunto das garantias processuais ou instrumentais
(FERRAJOLI, 2002, p. 432).

A despeito de não constituir objetivo deste artigo a análise das garantias penais previamente estabelecidas pelo jurista italiano em sua obra, faz-se necessário explicitar que a

\footnotetext{
${ }^{4}$ A1 Nulla poena sine crimine; A2 Nullum crimen sine lege; A3 Nulla lex (poenalis) sine necessitate; A4 Nulla necessitas sine injuria; A5 Nulla injuria sine actione; A6 Nulla actio sine culpa; A7 Nulla culpa sine iudicio; A8 Nullum iudicium sine accusatione; A9 Nulla accusatio sine probatione; A10 Nulla probatio sine defensione. (FERRAJOLI, 2002, p. 74-75).
} 
supracitada tese $\mathrm{T} 72$ representa uma junção do axioma A7 com os axiomas anteriores (relativos às garantias penais), isto é, do A1 ao A6. Demais disso, a tese T63 seria a união das garantias processuais remanescentes (A8, A9 e A10). Nesse sentido, ainda que não derivem um do outro, denota-se uma evidente concatenação sistemática entre os axiomas que compõem o modelo garantista, ou, de outro modo, o axioma subsequente como expressão de uma relação de continuidade para com o anterior.

Percebe-se, pois, que enquanto o axioma A7, por si só, afirmaria que não há culpa sem processo, a tese $\mathrm{T} 72$ vai adiante ao enfatizar as garantias penais como condicionantes da culpa, e, por conseguinte, igualmente condicionadas pelo processo. Portanto, as garantias substanciais necessitarão do processo penal para que sejam devidamente concretizadas.

Por seu turno, a tese T63 preconiza que de nada adianta tão-somente afirmar a necessidade do processo para efetivação das garantias penais, mas que esse processo deve ser regido por garantias outras que permitam-no constituir de fato um juízo cognitivo ${ }^{5}$, baseado na falseabilidade das provas apresentadas por uma acusação dissociada do julgador. É, assim, a exigência de um processo penal acusatório, indispensavelmente amparado por um lastro probatório que deverá ser contraditado em um ambiente dialético e democrático por meio de uma ampla defesa.

Em síntese, é dizer que no modelo penal garantista

[...] não se admite nenhuma imposição de pena: sem que se produza a comissão de um delito; sem que ele esteja previamente tipificado por lei; sem que exista necessidade de sua proibição e punição; sem que os efeitos da conduta sejam lesivos para terceiros; sem o caráter exterior ou material da ação criminosa; sem a imputabilidade e culpabilidade do autor; e sem que tudo isso seja verificado através de uma prova empírica, levada pela acusação a um juiz imparcial em um processo público, contraditório, com amplitude de defesa e mediante um procedimento legalmente preestabelecido. ${ }^{6}$

Registre-se, ainda, que a submissão à jurisdição em sentido lato, de forma isolada, poderia facilmente comportar um processo autoritário ${ }^{7}$, de cunho inquisitivo, visto que não estaria condicionado a quaisquer garantias acerca do modelo cognitivo a ser contemplado, ou seja, garantias verdadeiramente procedimentais.

\footnotetext{
${ }^{5}$ Ferrajoli vai afirmar que é a verdade - ainda que se referindo a uma verdade meramente formal, desconectada de qualquer visão inquisitiva do processo como busca incessante de uma verdade substancial - que faz o juízo, e não a autoridade: "veritas, non auctoritas facit judicium." (FERRAJOLI, 2002, p. 32-40).

6 LOPES JR., Aury. A instrumentalidade garantista do processo penal. Disponível em: http://www.academia.edu/download/34336792/AURY LOPES__GARANTISMO_PENAL.pdf.

${ }^{7}$ Extremamente interessante é a lição do professor Javier Llobet Rodríguez sobre como um processo penal pode servir a um regime desapegado de qualquer noção de respeito aos direitos humanos e fundamentais, inclusive figurando como sustentáculo para práticas desumanas, e, mais do que isso, sobre como a estrutura autoritária desse processo representa uma repressão em si: "Em um Estado autoritário, além de estruturar-se o "processo" penal conforme postulados autoritários, de acordo com as características de um sistema inquisitorial, o que impera definitivamente é a arbitrariedade, já que não se estabelecem mecanismos eficazes para reclamar violações à normativa existente. Por isso mesmo, não se admite reclamações contra a atuação arbitrária da polícia, de modo que se chega num sistema paralelo de repressão policial de fato, que leva a que não se apresente os detidos ante uma autoridade judicial e a que sejam objeto das piores arbitrariedades, incluída a tortura, o desaparecimento forçado e o assassinato extrajudicial. Tudo isso vai unido à impunidade que se garante nos regimes autoritários aos violadores de direitos humanos. Assim, no regime nacional-socialista, ou mesmo nas ditaduras latinoamericanas, o "processo" penal estava a serviço da arbitrariedade, cumprindo simplesmente uma função de legitimação, resultando que a própria estruturação autoritária do "processo" penal era somente uma das formas de repressão, posto que quando se queria, se atuava simplesmente pela via policial de fato, detendo, torturando e matando, sem render contas algumas ante os tribunais.” (RODRÍGUEZ, 2019, p. 40).
} 
Advém, assim, da submissão à jurisdição em sentido estrito a exigência de observância à estrutura acusatória ${ }^{8}$ do processo penal, que pressupõe um juiz imparcial e independente, separado funcional e esteticamente ${ }^{9}$ da figura das partes, especialmente do acusador. Pressupõe, ainda, a atribuição do ônus probatório à acusação - haja vista ser o sujeito passivo presumidamente inocente ${ }^{10}$ - e o direito ao contraditório e ampla defesa.

É justamente em razão desse encadeamento que permeia o sistema formulado por Ferrajoli que se cria uma patente vinculação entre cada uma das garantias propostas, de tal sorte que a plena eficácia do sistema garantista está condicionada à sua observância integral. Mostrase necessária essa explicitação, pois, em se tratando de princípios de caráter deontológico ${ }^{11}$, torna-se possível o enfraquecimento de um - ou alguns - ainda que aparentemente subsistam os demais, todavia isso resultará, como consequência, na redução da eficácia do referido sistema ou na limitação de seu alcance.

Indo adiante, as garantias penais podem ser traduzidas pelo princípio da estrita legalidade, que será igualmente subdividido em dois: legalidade penal em sentido lato e estrito. A legalidade em sentido lato, ou mera legalidade, caracteriza-se por condicionar a infração penal e a pena à reserva legal, e pode ser expressa por meio da união dos axiomas A1 e A2, ou seja, nulla poena nullum crimen sine lege. Por outro lado, enquanto a mera legalidade prestase a submeter o juiz aos limites da lei, a legalidade penal em sentido estrito vai além ao submeter a validade da lei ao respeito das demais garantias, isto é, submete a criação da lei penal - ou sua validade, caso vigente - à observância de um conteúdo compatível com o sistema de garantias, e pode ser compreendido a partir da conexão dos axiomas A3, A4, A5 e A6: nulla

\footnotetext{
${ }^{8}$ Diga-se, a título de curiosidade, que a recente Lei 13.964/19 incluiu no Código de Processo Penal o art. $3^{\circ}$-A, consagrando expressamente a estrutura acusatória que deve nortear o processo penal brasileiro, embora uma interpretação sistemática da Constituição Federal a consagrasse desde 1988: “Art. $3^{\circ}$-A. O processo penal terá estrutura acusatória, vedadas a iniciativa do juiz na fase de investigação e a substituição da atuação probatória do órgão de acusação.” (BRASIL, 2019).

${ }^{9} \mathrm{Na}$ linha do que sustenta Lopes Jr. sobre a imparcialidade objetiva e a posição estrutural do julgador no processo, ao aduzir que muitas vezes a análise da imparcialidade subjetiva se mostra uma tarefa impossível, vez que exigiria uma incursão pelo estado anímico do julgador: "Para que exista imparcialidade objetiva, o juiz não pode praticar atos típicos de parte, como é a atuação ex officio na busca de provas ou na decretação de uma prisão. Viola a imparcialidade toda vez que o juiz, objetivamente, sair do local estruturalmente demarcado, qual seja, de afastamento da arena das partes." O julgador, portanto, "obrigatoriamente deve estar (e assim permanecer) em situação de afastamento da esfera de atuação das partes", pois "quando o juiz sai desse lugar de estranhamento e, descendo, se mistura na 'arena das partes', praticando atos típicos das partes (como é a iniciativa probatória, por exemplo), ele estruturalmente se coloca em posição de parcialidade (ou partialidade, na medida em que se confunde com as partes), ferindo de morte a garantia constitucional. É uma questão estrutural, objetivamente comprovável: basta que saia do seu lugar para decretar a quebra da igualdade, do contraditório, da própria estrutura dialética do processo. Inclusive, evidencia-se falta de uma estética (ou visibilidade) de imparcialidade." (LOPES JR., 2018, p. 104-105).

${ }^{10}$ Lopes Jr. sintetiza a presunção de inocência como o princípio reitor do processo, constituindo um dever de tratamento destinado ao réu cuja compreensão se dá mediante duas dimensões distintas: "Na dimensão interna, é um dever de tratamento imposto - inicialmente - ao juiz, determinando que a carga da prova seja inteiramente do acusador (pois, se o réu é inocente, não precisa provar nada) e que a dúvida conduza inexoravelmente à absolvição (in dubio pro reo); ainda na dimensão interna, implica severas restrições ao ab(uso) das prisões cautelares [...]. Enfim, na dimensão interna, a presunção de inocência impõe regras de tratamento e regras de julgamento para o juiz. Externamente ao processo, a presunção de inocência exige uma proteção contra a publicidade abusiva e a estigmatização (precoce) do réu. Significa dizer que a presunção de inocência (e também as garantias constitucionais da imagem, dignidade e privacidade) deve ser utilizada como verdadeiros limites democráticos à abusiva exploração midiática em torno do fato criminoso e do próprio processo judicial. O bizarro espetáculo montado pelo julgamento midiático deve ser coibido pela eficácia da presunção de inocência." (LOPES JR., Aury. Direito processual penal. 16 ed. São Paulo: Saraiva Educação, 2019, p. 98-99).

${ }^{11}$ Aliás, acerca do garantismo, como lembrou Norberto Bobbio ao prefaciar a obra de Ferrajoli, trata-se de "um modelo ideal, do qual nos podemos mais ou menos aproximar. Como modelo, representa uma meta que permanece como tal, ainda que não seja alcançada e não possa jamais ser alcançada inteiramente.” (FERRAJOLI, 2002, p. 9).
} 
lex poenalis sine necessitate, sine injuria, sine actione, sine culpa. "Graças ao primeiro princípio, a lei é condicionante; graças ao segundo, é condicionada" (FERRAJOLI, 2002, p. 76), conclui o autor italiano.

Sem pretensão de exaustividade, esclareça-se que Ferrajoli diferencia a lei válida da lei vigente. Para ele, ainda que se possa conceber uma validade formal à lei vigente por esta ter cumprido a formalidade exigida para sua criação, a lei válida propriamente dita deve estar indispensavelmente de acordo com os requisitos de validade material, ou de "legitimação jurídica substancial" (FERRAJOLI, 2002, p. 290). Em outras palavras, é dizer que a lei não poderá, de modo algum, atentar contra os direitos e garantias previstos constitucionalmente, sob pena de invalidade, eis que constituem verdadeiras balizas ao conteúdo da norma.

Assim, relembrando que o princípio da submissão à jurisdição é uma exigência das garantias penais e pressuposto das demais garantias processuais, conclui-se que ele pressupõe a estrita legalidade na medida em que o juiz se encontra submetido justamente aos limites da lei válida. Infere-se, então, um afastamento da ideia antiquada de sujeição acrítica à letra da lei, sendo, agora, a Constituição o principal marco vinculante da atuação jurisdicional:

[...] la sujeción del juez a la ley ya no es, como en el viejo paradigma positivista, sujeción a la letra de la ley, cualquiera que fuere su significado, sino sujeción a la ley en cuanto válida, es decir, coherente con la Constitución. [...] nunca sujeción a la ley de tipo acritico e incondicionado, sino sujeción ante todo a la Constitución, que impone al juez la crítica de las leyes inválidas a través de su re-interpretación en sentido constitucional y la denuncia de su inconstitucionalidad. (FERRAJOLI, 2004, p. 26).

Resumindo, se as garantias penais necessitam do processo para que possam ser devidamente efetivadas, diz-se que o processo pressupõe a existência de uma lei substancialmente válida que delimite seu campo de atuação. O processo penal, então, pressupõe a reserva absoluta da lei (FERRAJOLI, 2002, p. 76) para configurar-se como um "processo de cognição ou de comprovação" (FERRAJOLI, p. 32), evitando juízos arbitrários, dotados de discricionariedade e subjetivismo.

\subsection{Princípio da necessidade}

Seguindo o raciocínio acima traçado, mostra-se possível destacar, a partir do princípio nulla poena sine iudicio, que a imposição de uma pena deve inexoravelmente advir de um devido processo penal, não podendo dele prescindir. Com a extinção da vingança privada ${ }^{12}$ e a avocação do ius puniendi pelo Estado ${ }^{13}$, criou-se um verdadeiro monopólio estatal do poder de penar, de forma que só este possui legitimidade para tal.

É justamente nessa característica que reside a instrumentalidade do processo penal, ou seja, o meio necessário para que o Estado possa aplicar legitimamente uma pena. Essa imprescindibilidade do processo é a mais acentuada peculiaridade do processo penal e comporta uma diferença abissal deste com relação ao processo civil, tornando viável afirmar, desde já, que o "direito penal é despido de coerção direta e, ao contrário do direito privado, não tem

\footnotetext{
${ }^{12}$ É importante a lição de Ferrajoli quando recusa a ideia da pena como estatização da vingança privada, aduzindo que geraria uma noção de continuidade que não ocorrera. Para ele, então, a pena estatal é uma expressão de descontinuidade - ou rompimento - porquanto autêntica negação da vingança privada, prestando-se a impedi-la. (FERRAJOLI, 2002, p. 269).

${ }^{13}$ Fazendo alusão ao contrato social, Beccaria diz que os indivíduos cederam parte de sua liberdade em prol de mais segurança, constituindo o conjunto dessas partes renunciadas a origem e o fundamento do direito de punir. (BECCARIA, 2015, p. 23-24).
} 
atuação nem realidade concreta fora do processo correspondente.” (LOPES JR., 2018, p. 52). Tem-se, aqui, o princípio da necessidade.

Compreendido esse caráter instrumental, poder-se-ia afirmar que o processo penal é um instrumento concebido para a efetivação do preceito secundário previsto numa norma penal incriminadora. Fato é que, partindo única e exclusivamente dessa premissa, o processo penal seria um instrumento a serviço da punição, e decerto seria uma afirmação plausível.

Porém, cumpre notar que esse pensamento desconsidera toda a vinculação que sofre a imposição de uma pena perante o respeito aos direitos e garantias fundamentais, ou, se não desconsidera, ao menos desloca para um segundo plano. Ainda que possa parecer uma questão meramente discursiva, o que se tem na verdade é uma anomalia, uma vez que as limitações ao poder punitivo acabam sendo interpretadas secundariamente ao poder punitivo em si, obtendo este último preferência em comparação ao primeiro. Assim, antes decide-se pela punição e, depois, contornam-se as limitações a ela impostas: são os fins moldando os meios.

É evidente que essa concepção não deve prosperar em um Estado Democrático de Direito que prima pela liberdade e respeito aos direitos individuais. O processo penal, portanto, antes de compor um instrumento punitivo, compõe um notório instrumento de proteção à dignidade da pessoa humana. ${ }^{14}$ Deve-se compreendê-lo como um instrumento de concretização do projeto democrático que deve cumprir a sua "finalidade constitucional-garantidora da máxima eficácia dos direitos e garantias fundamentais" (LOPES JR., 2018, p. 55). É essa a função constitucional do processo.

Lopes Jr., então, dá o nome de instrumentalidade constitucional à tal característica, sustentando que reside nela o fundamento de existência do processo criminal na contemporaneidade:

[...] concluímos que a instrumentalidade do processo penal é o fundamento de sua existência, mas com uma especial característica: é um instrumento de proteção dos direitos e garantias individuais. É uma especial conotação do caráter instrumental que só se manifesta no processo penal, pois se trata de instrumentalidade relacionada ao direito penal e à pena, mas, principalmente, um instrumento a serviço da máxima eficácia das garantias constitucionais. Está legitimado enquanto instrumento a serviço do projeto constitucional (LOPES JR., 2018, p. 58).

É essencial relembrar que o processo não é - ou, melhor dizendo, nem sempre foi propriamente uma exigência da pena, mas sim uma exigência de conquistas civilizatórias que não nos permitem retroagir enquanto sociedade. Com base em tudo isso, conclui-se que o processo penal não possui qualquer motivo para existir senão para proteger o indivíduo do arbítrio estatal, até porque, caso inexistisse tal pretensão, para quê mais precisaríamos de processo?

\section{PRETENSÃo ACUSATÓRIA COMO OBJETO DO PROCESSO PENAL DEMOCRÁTICO}

Uma vez abordado o fundamento do processo penal, cabe destacar que será mediante uma análise de seu objeto que se mostrará possível delimitar satisfatoriamente um campo de atuação de cunho democrático, visto que em torno dele desenvolver-se-á todo o processo e a atividade das partes, bem como a compreensão acerca dos limites direcionados a cada uma delas e ao próprio julgador.

\footnotetext{
${ }^{14}$ É nesse contexto que se diz, como lembra Rodríguez em referência ao jurista Winfried Hassemer, que as formas no processo penal não podem ser consideradas mero formalismo. (RODRÍGUEZ, 2019, p. 37).
} 
Mesmo não sendo objetivo do presente trabalho a exposição do conceito de lide, algumas breves considerações devem ser feitas. A primeira é que se trata, para efeitos desse artigo, de conceito inadequado ao processo penal em virtude da proeminência do supramencionado princípio da necessidade (nulla poena sine iudicio). Ora, se a lide ${ }^{15}$ é tida, na sua acepção clássica, como o conflito de interesses qualificado por uma pretensão resistida a ser satisfeita mediante o exercício da jurisdição, diz-se que no processo penal esse conflito de interesses - assim como qualquer resistência - torna-se irrelevante porquanto o direito penal não é autoexecutável, sendo inviável pensar-se numa pena sem um prévio processo. A jurisdição penal é imprescindível e inafastável.

Para além da lide, ocorre que a pretensão carneluttiana também foi amplamente difundida no processo penal em função da transposição conceitual engendrada pela teoria geral do processo, sendo ela comumente definida como a exigência de subordinação de um interesse alheio ao interesse próprio. Percebe-se, assim, que a pretensão não constitui um direito subjetivo, senão que a exigência de satisfação desse direito por outrem, ou, uma vez resistida, pela jurisdição estatal.

No âmbito processual penal, algumas construções foram sedimentadas e são aplicadas de forma tão automática que seria possível dizer que foram naturalizadas. Por este ângulo, ao tematizarmos parte dessas construções, verificamos que é preciso analisar suas origens para aferir se realmente se coadunam com um processo democrático como o aqui assumido, o qual, em nossa leitura, é uma exigência da contemporaneidade.

Por isso, cumpre notar que as lições introdutórias da pretensão em matéria criminal são atribuídas, dentre outros, ao jurista alemão Karl Binding (LOPES JR., 2018, p. 248-255), que sustentou o surgimento de uma verdadeira exigência punitiva como consequência da lesão a determinado bem jurídico por meio da prática de uma infração penal. Nessa linha argumentativa, praticado o crime, surge a exigibilidade da punição, de modo que o acusador figura como um autêntico credor, solicitando em juízo a procedência de sua pretensão que, em resumo, objetiva a adjudicação de uma pena.

Demais disso, Amaral e Gloeckner (2019) lembram enfaticamente que essa construção teórica em torno do que seria uma pretensão punitiva foi aprimorada no direito penal fascista. Sob a batuta de Arturo Rocco, o direito de punir foi tido como um direito subjetivo do Estado em face do suposto infrator, e estaria atrelado a um notório "direito de supremacia, ou seja, derivado de um status geral de subordinação e obediência política frente ao ente estatal." (AMARAL; GLOECKNER, 2019, p. 1033). Percebe-se que, enquanto o Estado possuiria um direito de supremacia, ao indivíduo caberia apenas um dever de obediência a esse referido direito estatal, de forma que, violado tal dever, surgiria para o Estado o direito de punir (GLOECKNER, 2011).

Portanto, seguindo essa linha, da lesão ao bem jurídico tem-se um direito subjetivo público lastreado em um dito interesse social pela repressão às condutas delitivas, e da

\footnotetext{
${ }^{15}$ É de grande valia a revisão feita por Jobim e Gloeckner acerca da evolução na compreensão do próprio Carnelutti sobre o conteúdo do processo penal, quando sustentam três alterações substanciais no pensamento do jurista italiano: inicialmente, afirmam que o conceito de lide era transportado na sua integralidade a fim de traduzir o objeto do processo penal, mas que essa posição foi suavizada no longínquo ano de 1941, quando Carnelutti passou a enxergá-lo em uma posição intermediária entre jurisdição contenciosa e voluntária. Nessa compreensão firmouse a "recepção da lide penal, como um conflito de pretensões, simples e sinteticamente, entre jus puniendi e status libertatis", todavia, em 1946, quando escreve o já abordado artigo "Cenerentola", Carnelutti reconhece alguns erros ao perceber a inexistência de conflito de interesses no processo penal, de tal sorte que não poderia ser considerado contencioso e, portanto, "o processo teria assim um caráter misto, isto é, seria contencioso quanto ao processo civil e voluntário em relação ao penal", afastando-se, de certo modo, da teoria geral do processo. (AMARAL, Augusto Jobim do; GLOECKNER, Ricardo Jacobsen. Direito de Ação no Processo Penal: polêmicas e horizontes possíveis. Revista Eletrônica do Curso de Direito da UFSM. Disponível em: https://periodicos.ufsm.br/revistadireito/article/view/30765).
} 
exigibilidade desse direito subjetivo (de punir) nasce a pretensão punitiva ${ }^{16}$. Com isso, acentuou-se a interpretação, já criticada acima, do processo penal como mero instrumento a serviço da punição do suposto criminoso, recusando a noção do acusado como um sujeito de direitos, mas tão-somente um objeto do ius puniendi do Estado (AMARAL; GLOECKNER, 2019, p. 1034).

Nesse ponto, denota-se uma clara violação ao princípio fundamental da dignidade da pessoa humana na medida em que se enxerga o Estado voltado a si próprio, como se fosse um fim em si mesmo, esquecendo-se que ele nada mais é do que um meio para dar guarida e proteção ao indivíduo, o que representa, em última análise, uma inversão de valores (REISS, 2017, p. 82).

É bastante significativa a advertência que faz o professor Michel Reiss (2017, p. 65-88) no sentido de que sempre existirá conotação política em todo e qualquer discurso relativo a direitos humanos, e, à vista disso, esse viés político deve inexoravelmente dirigir-se à redução e combate aos excessos estatais:

[...] a perspectiva dos Direitos Humanos a ser considerada envolve a proteção dos mais vulneráveis contra os excessos estatais - já que o Estado é, via de regra, o principal agente violador. E é neste contexto que a democracia deve ter papel de destaque, vez que somente assim o cidadão será considerado um efetivo sujeito de direitos, e não um mero objeto do arbítrio do estado (REISS, 2017, p. 87).

Assim, quer se trate de direitos humanos, no plano do direito internacional, quer se trate de direitos fundamentais, no plano do direito interno, é essencial estabelecer que tais direitos "só podem ser concebidos visando à proteção dos mais vulneráveis" (REISS, 2017, p. 82), sendo temerária qualquer leitura relativista que conceda ao Estado uma preponderância ante os cidadãos com base nesses mesmos direitos.

Para além disso, a aceitação da proposta de Binding e Rocco traz alguns equívocos na medida em que desconsidera certas peculiaridades atinentes ao processo penal. O principal erro consiste na confusão acerca do sujeito passivo da relação material e do sujeito ativo da relação processual, e aqui reside o cerne da questão. É sabido que, enquanto a legitimação ativa no processo civil é aferida com base na relação de direito material alegada, no processo penal ela é eminentemente normativa. ${ }^{17}$

Ainda que sem pretender exaurir o assunto, aqui se mostra necessário um aparte para explicitar, como o faz Lopes Jr. ao discorrer acerca do objeto do processo penal, o conceito de pretensão processual formulado pelo jurista espanhol Jaime Guasp, cuja teorização se deu mediante duas bases, quais sejam, sociológica e jurídica. A primeira comporta uma pretensão social proveniente do fenômeno ou problema sociológico, que no caso se traduz pela prática de um delito, e essa, por sua vez, é o que vai dar azo à segunda, que se trata de pretensão jurídica.

Segundo Guasp, a tarefa que coube ao Direito, então, foi criar verdadeiras instituições artificiais que pudessem tutelar juridicamente essas questões sociais, retirando-as do âmbito puramente sociológico. É por isso que a pretensão jurídica é um "produto que o direito retira da pretensão social" (LOPES JR., 2018, p. 257), ou, ainda, "uma consequência jurídica de um estado de fato" (LOPES JR., 2018, p. 260).

\footnotetext{
16 “É este momento de direito sobre o réu que será chamado de pretensão jurídica (punitiva). E a ela corresponde uma obrigação - uma relação jurídica de caráter obrigatório (um dever jurídico) é estabelecida. Relação jurídica obrigatória, afinal punitiva, a que está obrigada a pessoa do réu." (AMARAL; GLOECKNER, 2019, p. 1033).

17 “Ao Ministério Público foi conferido, apenas, a titularidade ou legitimidade para a propositura da ação penal. Tal poder, porém, decorre simplesmente da lei, independentemente da titularidade do "direito material" debatido em juízo". (BADARÓ, Gustavo Henrique Righi Ivahy. As condições da ação penal. Disponível em http://www.badaroadvogados.com.br/20-062017-as-condicoes-da-acao-penal.html).
} 
Sinteticamente, é dizer que a "pretensão social que nasceu com o delito é elevada ao status de pretensão jurídica de acusar, para possibilitar o nascimento do processo." (LOPES JR., 2018, p. 277). Frise-se, então, que no processo penal, mais especificamente em atenção à máxima nulla culpa nulla poena sine iudicio, será sempre uma pretensão jurídica processual, visto que só poderá ser satisfeita pela via do devido processo.

O grande problema em sustentar que, a partir do fato criminoso, nasceria para o acusador uma pretensão exequível mediante a adjudicação de um direito subjetivo de punir se dá na medida em que se lhe atribui erroneamente a titularidade do ius puniendi. Um dos sustentáculos dessa concepção é justamente inserir o acusador em um conflito de interesses que é intrinsecamente material e, depois, extrair desse conflito a exigibilidade da punição, como se estivesse a postular um direito próprio.

No entanto, sublinhe-se que o acusador, seja ele público ou privado, não figura como titular do direito de punir e tampouco requer ao juízo que lhe seja concedido tal direito. ${ }^{18} \mathrm{O}$ ius puniendi que poderá eventualmente ser exercido no processo penal é de titularidade exclusiva do Estado-juiz e configura-se como um poder condicionado ao exercício regular de uma acusação e limitado pela principiologia constitucional-garantista exposta anteriormente.

Feita tal consideração sobre a titularidade do direito de punir, destaque-se que na acusação "não se faz valer uma exigência punitiva, senão que se cria tão-somente o pressuposto necessário para que o órgão jurisdicional possa proceder à averiguação do delito e de seu autor e impor a pena ao culpado."19

Forçoso concluir, partindo desse raciocínio, que o único conflito de interesses que pode eventualmente surgir da prática de uma infração penal diz respeito ao conflito material em si, entre ofensor e ofendido, mas jamais entre acusador e réu. Isso porque, desde há muito, extinguiu-se a autotutela e a vingança privada, de tal maneira que a única pretensão ou exigência punitiva que poderia vir a ser admitida, de caráter unicamente social e despida de base jurídica, não mais possui relevância concreta para o Direito.

Assim, admitindo o conceito de pretensão processual anteriormente mencionado e compreendido que essa referida pretensão não decorre de conflito de interesses, afirma-se que ela advém verdadeiramente de um "direito potestativo de acusar decorrente do ataque a um bem jurídico e cujo exercício é imprescindível para que se permita a efetivação do poder de penar" (LOPES JR., 2018, p. 251).

Com efeito, conclui-se que o acusador é titular do ius ut procedatur ${ }^{20}$, definido como o "direito meramente formal de acusar" (ORBANEJA; QUEMADA, 1987, p. 89), constituindo um poder normativamente conferido de proceder contra alguém, ou poder de invocação da tutela jurisdicional em matéria penal, atribuído por força de lei.

Consequentemente, o acusador não ostenta qualquer incumbência de punição de eventual criminoso, mas apenas de promovê-la quando presentes determinados requisitos. Por mais que pareça uma assertiva banal, tal compreensão é de enorme relevância para uma

\footnotetext{
${ }^{18}$ Aliás, diga-se de passagem, sequer exige-se da acusação qualquer menção à cominação da pena, regime prisional ou qualquer outra característica referente à aplicação da punição, uma vez que tudo isso será efetuado exclusivamente pelo julgador.

19 Tradução livre de: "Mediante la acusación no se hace valer una exigencia punitiva, sino se crea tan sólo el presupuesto necesario para que el órgano jurisdiccional pueda proceder a la averiguación del delito y de su autor e imponer la pena al culpable." (ORBANEJA; QUEMADA, 1987, p. 89-90).

${ }^{20}$ Com base nisso, poder-se-ia sustentar uma recusa à noção de "legitimação extraordinária" mediante substituição processual no processo penal, comumente atribuída aos casos de ação penal de iniciativa privada. Isso dado que o particular não estaria postulando em nome próprio um direito alheio, rotineiramente reconhecido como o ius puniendi, mas sim exercendo a atribuição acusatória que lhe fora concedida por lei. Por outro lado, seria mais viável pensar-se em uma possível legitimação extraordinária nos casos de ação penal de iniciativa privada subsidiária da pública, porém tal assunto extrapola a finalidade do presente artigo.
} 
delimitação satisfatória da atuação ministerial (ou do particular, quando tratar-se de ação penal de iniciativa privada) e do julgador ao longo da persecução criminal.

Ademais, o ius ut procedatur será devidamente manifestado na denúncia ou queixacrime por meio da denominada pretensão processual acusatória, conceituada por Lopes Jr. como "uma declaração petitória de que existe o direito potestativo de acusar e que procede a aplicação do poder punitivo estatal." (LOPES JR., 2018, p. 259). Esclareça-se que o autor se debruça em três elementos componentes da pretensão acusatória, que serão brevemente abordados a fim de permitir um melhor aprofundamento sobre o tema.

O primeiro deles é o elemento subjetivo, que diz respeito à legitimação dos sujeitos do processo. Conforme já pontuado, a legitimidade ativa no processo penal é aferida com base em critérios puramente normativos, isto é, será legitimado para propor ação penal aquele que a lei definir como tal. De forma majoritária, será o Ministério Público, por força do art. 129, I, da $\mathrm{CF} / 88$, que prevê como atribuição privativa do órgão ministerial a propositura das ações penais públicas, em que pese a lei conferir tal atribuição ao ofendido, por razões de política criminal, nas chamadas ações penais privadas ${ }^{21}$.

Além disso, é preciso atentar-se para o sujeito passivo, que é o elemento subjetivo determinante da relação processual penal e caracteriza-se pela pessoa do acusado. Em outras palavras, trata-se do suposto autor do fato criminoso descrito na peça inicial, sendo inexorável a sua individualização, bem como de sua suposta conduta delitiva. Por fim, em posição alheia às partes, tem-se o Estado-juiz, com competência jurisdicional previamente definida em atenção ao princípio do juiz natural, que procederá ao processamento e julgamento do feito. A propósito, como fora asseverado nos tópicos anteriores, ressalte-se que este deve reger-se pela inércia, imparcialidade e independência, sem prejuízo da estrita observância às demais garantias já citadas.

Em seguida, advindo do fenômeno social aludido por Guasp ${ }^{22}$, aparece o elemento objetivo, que é, basicamente, o fato criminoso sobre o qual se baseia a denúncia ou queixacrime. Lopes Jr. sintetiza que "o fato aparentemente punível não é o objeto do processo, mas um elemento integrante da pretensão", visto que, existindo o fato punível ou caso penal, ainda assim faltaria algo que pudesse efetivamente dar ensejo à atividade jurisdicional e proporcionar a satisfação jurídica da pretensão.

Essa constatação justifica-se na medida em que o conflito material, por si só, não possui o condão de proporcionar um suporte jurídico apto a iniciar um processo criminal. Tendo isso em vista, sustenta o autor que o objeto do processo não poderia ser tal conflito, pois insuficiente, mas sim a pretensão processual acusatória c omo um todo, cujo conteúdo traduz-se no caso penal como elemento integrante. (LOPES JR., 2018, p. 262-263).

\footnotetext{
${ }^{21}$ É importante enfatizar a chamada ação penal privada subsidiária da pública, que garante ao ofendido a possibilidade de propor a ação quando o Ministério Público se mantém inerte e não a propõe no prazo legal. Está prevista no art. $5^{\circ}$, LIX, da CF/88 e no art. 29 do CPP. Ainda que tal situação possa se amoldar à legitimação extraordinária, como dito alhures, mostra-se mais condizente a terminologia sugerida por Badaró: “[...] em regra, há uma legitimação concorrente, na qual o Ministério Público é o legitimado primário e o ofendido o legitimado subsidiário." (BADARÓ, Gustavo Henrique Righi Ivahy. As condições da ação penal. Disponível em http://www.badaroadvogados.com.br/20-062017-as-condicoes-da-acao-penal.html)

${ }^{22}$ É pertinente citar a observação feita por Lopes Jr. de que, para Guasp, o fato que compõe a pretensão é a "soma de acontecimentos concretos, históricos, despidos de qualificação jurídica", de forma similar ao princípio iura novit curia e à máxima narra mihi factum dabo tibi jus. Nessa linha, o professor gaúcho adverte que tal pensamento serve de sustentáculo para a noção de que o julgador se vê adstrito aos fatos narrados, e não à capitulação penal escolhida, motivo pelo qual são previstos institutos como a emendatio e mutatio libelli (art. 383 e art. 384 do CPP). No entanto, apenas frise-se que essa "dicotomia entre fato natural e qualificação jurídica é, em termos processuais, ingênua e perigosa", uma vez que "o réu se defende do fato e, ao mesmo tempo, incumbe ao defensor, também, debruçar-se em limites semânticos do tipo", mostrando-se inegável que a atuação defensiva se dá nos limites da imputação penal, que será verdadeira "pedra angular onde desenvolverá suas teses”. (LOPES JR., 2018, p. 263).
} 
Por último, falta justamente a formalização de uma acusação, pautada pelos elementos subjetivo e objetivo já explicitados, para dar causa ao processo penal. Nos dizeres de Lopes Jr. (2018, p. 265), o que falta é o ato capaz de causar a modificação da realidade que a pretensão leva consigo, representado por uma declaração de vontade que pede a realização da pretensão ou, por assim dizer, uma declaração petitória.

De forma concisa, a declaração petitória nada mais é do que uma manifestação de vontade exarada em um instrumento formal de acusação por meio do qual será descrita a prática de uma infração penal, efetivando o poder invocatório e requerendo ao órgão jurisdicional o exercício do poder punitivo em desfavor do suposto autor da conduta delitiva.

Portanto, é somente ao visualizar o acusador de maneira desconectada de qualquer resquício de modelos inquisitivos de processo penal, como a exigência punitiva ou o direito de supremacia, que se torna viável delimitar substancialmente o campo destinado a cada um dos sujeitos processuais, incluindo o próprio Estado-juiz. Dito de outra forma, se ao acusador não cumpre qualquer poder punitivo, ao julgador também não cumpre qualquer poder persecutório $^{23}$, e essa esfera de atividade não poderá ser extrapolada.

Eis, em síntese, uma breve explanação do que seria a pretensão acusatória como objeto de um processo penal contemporâneo, cuja atuação das partes se encontra categoricamente definida a partir do intuito de conformar um processo penal mais democrático, no qual os cidadãos não percam sua dimensão de sujeitos de direitos e garantias, visto que a pretensão acusatória deve necessariamente desassociar-se de posições interpretativas autoritárias, guiadas por um espetáculo punitivo ou pelo mero anseio de punir, ainda que ao custo das próprias garantias fundamentais. Isto é, o modelo processual aqui defendido, tendo como chave interpretativa os pressupostos conceituais que assumimos, pode potencializar a emergência de condições que, pouco a pouco, sejam capazes de configurar um exercício não apenas legal do ius puniendi, mas também refletindo uma dimensão de legitimidade ampliada.

\section{CONSIDERAÇÕES FINAIS}

Analisar um processo penal democrático passa necessariamente por abordar um processo lastreado no princípio da dignidade da pessoa humana e regido por garantias constitucionais que se destinem à limitação do poder punitivo estatal. Passa, basicamente, por compreender a vulnerabilidade do indivíduo quando colocado em confronto com o Estado, independentemente de características externas ou subjetivas, mas tão-somente em virtude da sua condição enquanto pessoa. É entender a valorização do indivíduo e a sua prevalência perante os interesses do Estado, que jamais poderão ser manipulados como interesses da sociedade por meio de um utilitarismo processual dissimulado que, em suma, reflete um pensamento autoritário e reduz os direitos individuais ao menoscabo.

Nessa linha, o presente artigo procurou, de início, investigar os fundamentos do processo penal sob o prisma da teoria garantista formulada por Ferrajoli, com ênfase nas garantias processuais penais, expressando, mediante ambos os sentidos atribuídos ao princípio da jurisdicionariedade, a proeminência que deve ocupar o processo penal na qualidade de juízo cognitivo, racional, norteado por seus princípios constitucionais e despido de arbitrariedades e subjetivismos. Em seguida, acentuou-se a exigência do devido processo para o exercício legítimo do ius puniendi como verdadeira conquista civilizatória (nulla poena nulla culpa sine iudicio). Uma pena só há de ser imposta se perpassado todo o procedimento de comprovação em estrita observância às garantias do réu, de forma que, caso contrário, o poder punitivo, pelo menos em tese, não poderia ser exercido.

\footnotetext{
${ }^{23}$ Privilegiando, assim, o sistema acusatório e todas as demais garantias a ele intrínsecas, como a imparcialidade e a presunção de inocência.
} 
É dizer que nesse estágio da democracia constitucional que nos encontramos, a dignidade da pessoa humana "confere unidade de sentido aos direitos fundamentais, impondo um esquadro de limitações ao Direito penal" (SEMER, 2020, p. 46) e, consequentemente, "projeta sentido a todos os princípios penais" (SEMER, 2020, p. 47). Nesse contexto torna-se plausível mencionar a razão básica de existir do processo criminal, que em nada mais reside senão na tutela e na concretização dos direitos e garantias individuais, figurando a Constituição Federal, em linhas gerais, como seu fundamento precípuo.

Para além disso, o objeto do processo também se mostrou um ponto fundamental na demonstração das ponderações supracitadas. Isso porque abarca todas as preocupações manifestadas, tanto a imprescindibilidade de proceder a uma releitura de sua conceituação quanto de adequá-lo aos imperativos democrático-constitucionais. Explicou-se que a sua origem advém primordialmente de teorizações carneluttianas - lide e pretensão - propriamente pensadas para os fenômenos do processo civil e que nunca lograram êxito em solucionar controvérsias no âmbito do direito processual penal. Ademais, o conceito acabou sendo alvo de adaptações que o levaram a assumir feições verdadeiramente autoritárias, típicas de modelos inquisitivos de processo penal, especialmente da dogmática fascista.

Tais adaptações, de forma concisa, conceberam ao acusador um tipo de pretensão punitiva, calcada inicialmente em um dito direito de supremacia do Estado perante o indivíduo, com base justamente na submissão do interesse alheio ao interesse próprio que é característica da pretensão carneluttiana. Sem adentrar novamente nos debates já trazidos ao longo do trabalho, fato é que esse entendimento confere ao acusador a titularidade do direito de punir e, mais ainda, garante ao Estado uma preponderância ilimitada perante os cidadãos. É uma visão que enxerga o acusado como mero objeto do poder punitivo estatal e não se coaduna com os princípios e garantias mais basilares que buscamos expor nesse artigo. Não há, portanto, como conciliar a pretensão punitiva com o fundamento precípuo do processo penal democrático. Admitir o contrário seria admitir a sua completa deturpação, ou seja, o processo enquanto instrumento de garantia da vontade punitiva do Estado.

Tendo isso em vista, discorreu-se sobre a pretensão acusatória como objeto do processo penal, desvinculada de qualquer anseio punitivo ou conflito material de interesses. Com base nesse conceito, se atribui ao acusador a titularidade do ius ut procedatur, enquanto o ius puniendi se torna incumbência exclusiva do julgador, e o seu exercício resta, simultaneamente, condicionado a uma acusação regular e limitado pelas garantias constitucionais. Em resumo, delimita-se especificamente a atuação de cada parte e do julgador ao longo da persecução penal e recusa-se eventuais compreensões do processo como instrumento gerador de violência ou a serviço da punição, facilitando a sua materialização como instrumento de tutela, ou, por assim dizer, instrumento democrático destinado à proteção dos direitos e garantias fundamentais da pessoa ante o poderio estatal.

\section{REFERÊNCIAS}

AMARAL, Augusto Jobim do; GLOECKNER, Ricardo Jacobsen. Direito de Ação no Processo Penal: polêmicas e horizontes possíveis. Revista Eletrônica do Curso de Direito da UFSM. Disponível em: https://periodicos.ufsm.br/revistadireito/article/view/30765. Acesso em 15 set. 2020.

BADARÓ, Gustavo Henrique Righi Ivahy. As condições da ação penal. Disponível em http://www.badaroadvogados.com.br/20-062017-as-condicoes-da-acao-penal.html. Acesso em 15 set. 2020 . 
BRASIL. Código de Processo Penal. Brasília, DF: Presidência da República, 2020. Disponível em: http://www.planalto.gov.br/ccivil_03/decreto-lei/del3689compilado.htm. Acesso em: 12 jun. 2020.

BRASIL. Constituição da República Federativa do Brasil. Brasília, DF: Presidência da República, 2020. Disponível em:

http://www.planalto.gov.br/ccivil_03/constituicao/constituicao.htm. Acesso em: 12 jun. 2020.

BRASIL. Supremo Tribunal Federal. Arguição de Descumprimento de Preceito Fundamental 347 MC/DF, 2015. Rel. Min. Marco Aurélio. Disponível em: http://redir.stf.jus.br/paginadorpub/paginador.jsp?docTP=TP\&docID=10300665. Acesso em: 15 set. 2020.

CRUZ, Rogério Schietti M. Rumo a um processo penal democrático. Revista da EMERJ, Rio de Janeiro, v. 21, n. 3, t. 1, 2019, p. 41. Disponível em: https://www.emerj.tjrj.jus.br/revistaemerj_online/edicoes/revista_v21_n3/tomo1/revista_v21_ n3_tomo1_36.pdf. Acesso em: 20 jul. 2020.

DIAS, Ronaldo Brêtas de Carvalho. Processo Constitucional e Estado Democrático de Direito. 3 ed. Belo Horizonte: Editora Del Rey, 2015.

DIDIER JR., Fredie. Curso de direito processual civil: introdução ao processo civil, parte geral e processo de conhecimento. 21 ed. Salvador: Editora Jus Podivm, 2019.

FERNANDES, Bernardo Gonçalves. Curso de direito constitucional. 7 ed. Salvador: Editora Jus Podivm, 2015.

FERRAJOLI, Luigi. Derechos y garantías. La ley del más débil. 4 ed. Madrid: Trotta, 2004.

FERRAJOLI, Luigi. Direito e razão: teoria do garantismo penal. 3 ed. São Paulo: Editora Revista dos Tribunais, 2002.

FRAGOSO, Heleno Cláudio. Lições de direito penal: parte geral.16 ed. Rio de Janeiro: Forense, 2004.

GLOECKNER, Ricardo Jacobsen. Inaplicabilidade do conceito de ação ao processo penal. In: Sistema penal e violência. Revista Eletrônica da Faculdade de Direito da PUC/RS. Disponível em: http://repositorio.pucrs.br/dspace/bitstream/10923/11379/2/Inaplicabilidade_do_Conceito_de Acao_ao_Processo_Penal.pdf. Acesso em 15 set. 2020.

GÓMEZ ORBANEJA, Emilio. HERCE QUEMADA, Vicente. Derecho Procesal Penal. 10 ed. Madrid: Artes Gráficas y Ediciones S. A., 1987.

LOPES JR., Aury. A instrumentalidade garantista do processo penal. Disponível em http://www.academia.edu/download/34336792/AURY_LOPES_GARANTISMO_PENAL.p df. Acesso em: 15 set. 2020.

LOPES JR., Aury. Direito Processual Penal. 16 ed. São Paulo: Editora Saraiva, 2019. 
LOPES JR., Aury. Fundamentos do Processo Penal: introdução crítica. 4 ed. São Paulo: Editora Saraiva, 2018.

REISS, Michel Wencland. Tribunal Penal Internacional: construindo o direito internacional penal. Belo Horizonte: Editora D'Plácido, 2017.

RODRÍGUEZ, Javier Llobet. Nacional-socialismo e antigarantismo penal (1933-1945). Tradução de Paulo César Busato. 1 ed. São Paulo: Tirant Lo Blanch Teoria, 2019.

ROSA, Alexandre Morais da. Decisão no processo penal como bricolage de significantes. Tese (Doutorado em Direito). Universidade Federal do Paraná: Curitiba, 2004.

SEMER, Marcelo. Princípios Penais no Estado Democrático de Direito. 1 ed. São Paulo: Tirant Lo Blanch, 2020. 